\title{
Red cell indices and serum ferritin levels in children
}

\author{
JILL HOWS, SONAY HUSSEIN, A. V. HOFFBRAND, AND \\ S. N. WICKRAMASINGHE
}

From the Department of Haematology and MRC Experimental Haematology Unit, St. Mary's Hospital Medical School, Norfolk Place, W2 IPG and the Department of Haematology, Royal Free Hospital, Pond Street, Hampstead NW3 2QG

SUMMARY The blood counts of 187 non-anaemic children who attended hospital with minor illnesses and who were between the ages of 12 months and 6 years were studied retrospectively. As many as $76.8 \%$ of these children were found to have MCVs below the normal adult range. A prospective study of a further 28 non-anaemic children in the same age group showed that the majority of children with low MCVs have normal haemoglobin $\mathrm{A}_{2}$ and F levels and haveserum ferritin levels within the normal adult range. These findings indicate that microcytosis is an intrinsic feature of erythropoiesis in early childhood and that in most instances this feature cannot be attributed to iron deficiency or $\beta$-thalassaemia syndromes.

Previous authors have shown that many children whose haemoglobin concentrations are within the usually accepted normal range (above $10.8 \mathrm{~g} / \mathrm{dl}$ (World Health Organisation, 1959)) have a low mean corpuscular volume (MCV) and a low mean corpuscular haemoglobin $(\mathrm{MCH})$ compared with normal adults (Guest and Brown, 1957; Sturgeon, 1958; Schmaier et al., 1974) and have attributed these findings to a high prevalence of iron deficiency in children. The present study was undertaken to investigate the validity of this explanation. Our results clearly indicate that iron deficiency accounts for only a minor proportion of the microcytosis of childhood and that normal iron-replete children show microcytosis, their red cells being smaller the lower the age of the child.

\section{Material and methods}

\section{SUBJECTS STUDIED}

In a preliminary study, a retrospective analysis of the data from blood samples of 200 randomly selected children between the ages of 12 months and 6 years were made. Most of these children were suffering from trivial medical complaints or were having a routine blood count before planned minor surgery. Nineteen of the 200 children were excluded from the study because they had chronic diseases which might affect erythropoiesis or showed anaemia (ie, $\mathrm{Hb}<$
$10.8 \mathrm{~g} / \mathrm{dl}$ ) or were already known to have a haemoglobinopathy. As the children included in the retrospective study were drawn from a multiracial population, it is possible that undiagnosed thalassaemia syndromes, haemoglobinopathies or iron deficiency could have accounted for the high incidence of low MCVs and MCHs subsequently observed. These possibilities were investigated in a prospective study on a further 28 consecutive non-anaemic children aged between 22 months and 6 years attending an outpatient department. On these 28 children we performed blood counts, Sickledex tests, and haemoglobin electrophoresis and estimated haemoglobin $A_{2}$ and $F$ levels. Serum ferritin levels were assayed in 20 of the 28 children.

\section{METHODS}

Blood counts were performed on a Coulter Counter, Model S, standardised with 4C Coulter Counter cell control. Serum ferritin levels were assayed using the technique of Addison et al. (1972). In our hands, the mean serum ferritin level in 38 non-anaemic, normal adult females was $56.6 \mu \mathrm{g} / 1$ (range 14-148 $\mu \mathrm{g} / \mathrm{l}$ ) and in 39 non-anaemic normal adult males was $165.4 \mu \mathrm{g} / 1$ (range 39-340 $\mu \mathrm{g} / \mathrm{l}$ ). The haemoglobin studies were performed using standard techniques (Dacie and Lewis, 1975).

\section{Results}

The mean \pm 2 SD for the various parameters in- 
vestigated in the 181 patients studied retrospectively were: haemoglobin $12.3 \pm 1.7 \mathrm{~g} / \mathrm{dl}$; red cell count $4.64 \pm 0.76 \times 10^{12} / 1 ; \mathrm{MCV} 78.1 \pm 10.4 \mathrm{ff} ; \mathrm{MCH}$ $26.6 \pm 4.1 \mathrm{pg}$. The proportions of children having MCVs and MCHs below the normal adult ranges (Bain and England, 1975) of $89.5 \pm 7.5(2 \mathrm{SD}) \mathrm{fl}$ and $30.3 \pm 2.6$ ( 2 SD) $\mathrm{pg}$ were as high as $76.8 \%$ (Figure) and $69.6 \%$ respectively. In addition, the mean ( \pm 2 SD) for the MCV was found to be low, with a value of $79.9( \pm 9.0) \mathrm{fl}$, even when only the 67 children with haemoglobin levels above $12.4 \mathrm{~g} / \mathrm{dl}$ were considered. We also found that in the entire group of 181 children studied, the mean values for the MCV and MCH increased slightly, but progressively, with age from $76.5 \mathrm{fl}$ and $25.9 \mathrm{pg}$ between the ages of 1 and 3 years to $79.6 \mathrm{fl}(\mathrm{P}<0.02)$ and $27.4 \mathrm{pg}(\mathrm{P}<0.005)$ between the ages of 5 and 6 years.

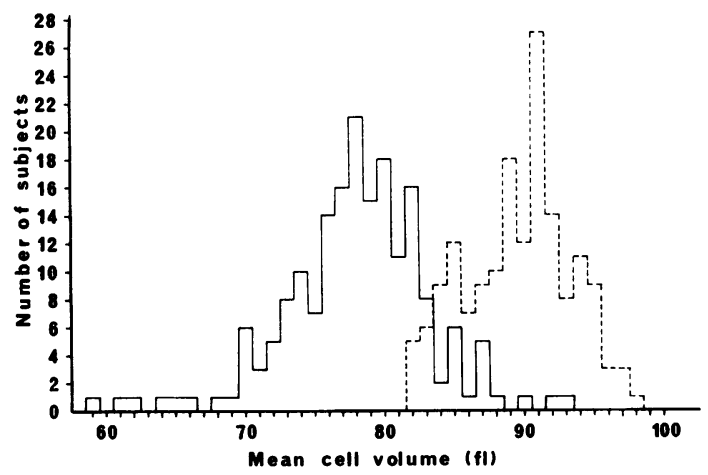

Figure Histogram of the frequency distribution of MCVs in the 181 children studied retrospectively (solid line) together with a histogram of the distribution of MCVs in an equal number of healthy adults (interrupted line).

Three of the 28 children in the prospective study were found to have a haemoglobinopathy or $\beta$ thalassaemia syndrome. The mean values for the MCV and MCH in the 25 patients without a haemoglobinopathy or $\beta$-thalassaemia syndrome in this prospective study were similar to those in the larger retrospective study, being $79.8 \mathrm{fl}$ and $26.8 \mathrm{pg}$ respectively. None of the 20 children in whom serum ferritin levels were assayed had a haemoglobinopathy or $\beta$-thalassaemia syndrome. Despite the high prevalence of the low MCVs and MCHs in these children only one of them had serum ferritin levels below the normal adult range of 14 to 340 $\mu \mathrm{g} / \mathrm{l}$ and the mean serum ferritin level in the 20 children was $42 \cdot 2 \mu \mathrm{g} / \mathrm{l}$ (range 12-122 $\mu \mathrm{g} / \mathrm{l})$. There was no correlation between MCV and serum ferritin in these children.

\section{Discussion}

The data presented here indicate that many children with low MCVs and MCHs are not iron deficient, do not have thalassaemia, a haemoglobinopathy, or other cause for microcytosis, and suggest that the production of microcytes is an intrinsic feature of erythropoiesis in childhood and that this is independent of the iron status of the child. This concept is supported by the observations that infants given 250 $\mathrm{mg}$ iron dextran intramuscularly at the age of 9 months still show a low average MCV of 78.9 and $82.3 \mathrm{fl}$ when they reach the ages of 12 and 18 months respectively, despite the parenteral iron therapy (Sturgeon, 1958), and that although children with haemoglobin levels above $12.4 \mathrm{~g} / \mathrm{dl}$ have a low mean MCV (our data) such children do not increase their haemoglobin levels after six weeks of oral iron therapy (Evans et al., 1972).

The spontaneous rise in mean MCV with age, demonstrated in the present study in children between the ages of 1 and 6 years, has been shown to continue both in older children (Guest and Brown, 1957; Schmaier et al., 1974) and in adults (Stenhouse and Woodliff, 1974). These findings also suggest that microcytosis is an inherent phenomenon of erythro $\exists$ poiesis in childhood and that there is a graduif change to the production of red cells of adult size as the child grows.

We wish to thank Professor T. E. Oppé for valuable discussions during the course of this study.

\section{References}

Addison, G. M., Beamish, M. R., Hales, C. N., Hodgkins, M., Jacobs, A., and Llewellin, P. (1972). An immunoradiometric assay for ferritin in the serum of normal subjects and patients with iron deficiency and iron overload. Journal of Clinical Pathology, 25, 326-329.

Bain, B. J. and England, J. M. (1975). Normal haematological values: sex difference in neutrophil count. British Medical Journal, 1, 306-309.

Dacie, J. V. and Lewis, S. M. (1975). Practical Haematology, D 5th edition. Churchill Livingstone, Edinburgh.

Evans, D. M. D., Lewis, J., and Curran, E. (1972). Haemoglobin levels in Cardiff children of nursery school age. $\mathrm{N}$ Archives of Disease in Childhood, 47, 772-776.

Guest, G. M. and Brown, E. W. (1957). Erythrocytes and $\mathcal{O}$ hemoglobin of the blood in infancy and childhood. III. N

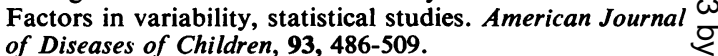

Schmaier, A. H., Maurer, H. M., Johnston, C. L., Scott, $\varrho$ R. B., and Stewart, L. M. (1974). Electronically deter- $\frac{}{\Phi}$ mined red cell indices in a predominantly black urban of population of children 4 to 8 years of age. Journal of Pediatrics, 84, 559-561.

Stenhouse, N. and Woodliff, H. J. (1974). Red cell indices $\stackrel{\vec{P}}{\vec{P}}$ and age. Medical Journal of Australia, 2, 614.

Sturgeon. P. (1958). Studies of iron requirements in infants 
and children. In Iron in Clinical Medicine, edited by R. $O$. Wallerstein and S. R. Mettier, pp. 183-203. University of California Press, Berkeley and Los Angeles.
World Health Organization (1959). Iron deficiency anaemia: report of a Study Group. W.H.O. Technical Report Series, 182.

\section{Reports and Bulletins prepared by the Association of Clinical Biochemists}

The following reports and bulletins are published by the Association of Clinical Biochemists. They may be obtained from The Publishing Department, British Medical Journal (ACB Technical Bulletins), B.M.A. House, Tavistock Square, London WC1H 9JR. Overseas readers should remit by British Postal or Money Order.

SCIENTIFIC REPORTS (price $£ 1 \cdot 00 / \$ 2.00$ each)

3 Automatic Dispensing Pipettes: an assessment of 35 commercial instruments September 1967 P. M. G. BROUGHTON, A. H. GOWENLOCK, G. M. WIDDOWSON, and K. A. AHLQUIST

4 An Evaluation of five Commercial Flame Photometers suitable for the Simultaneous Determination of Sodium and Potassium March 1970 P. M. G. BROUGHTON and J. B. DAWSON

SCIENTIFIC REVIEWS (price $£ 1.00 / \$ 2.00$ each)

1 The Assessment of Thyroid Function March 1971 F. V. FLYNN and J. R. HOBBS

2 Renal Function Tests Suitable for Clinical Practice January 1972 F. L. MTCHELL, N. VEALL, and R. W. E. WATTS

3 Biochemical Tests for the Assessment of Fetoplacental Function May 1975 C. E. WILDE and R. E. OAKEY

TECHNICAL BULLETINS (price $£ 1 \cdot 00 / \$ 2.00$ each)

9 Determination of Urea by AutoAnalyzer November 1966 RUTH M. HASLAM

11 Determination of Serum Albumin by AutoAnalyzer using Bromocresol Green October 1967 B. E. NORTHAM and G. M. WIDDOWSON

13 An Assessment of the Technicon Type II Sampler Unit March 1968 B. C. GRAY and G. K. McGOWAN

14 Atomic Absorption Spectroscopy: an outline of its principles and a guide to the selection of instruments May 1968 J. B. DAWSON and P. M. G. BROUGHTON

15 A Guide to Automatic Pipettes (2nd edition) June 1968 P. M. G. BROUGHTON

16 A Guide to Automation in Clinical Chemistry May 1969 P. M. G. BROUGHTON

17 Flame Photometers: a comparative list of 17 instruments readily available in Britain August $1969 \mathrm{P}$. WIIDING

19 Spectrophotometers: a comparative list of low-priced instruments readily available in Britain May 1970 C. E. WILDE and P. SEWELL
20 Quantities and Units in Clinical Biochemistry June 1970 P. M. G. BROUGHTON

21 Filter Fluorimeters: A comparative list of 18 instruments September 1970 H. BRAUNSBERG and S. S. BROWN 22 Bilirubin Standards and the Determination of Bilirubin by Manual and Technicon AutoAnalyzer Methods January 1971 BARBARA BILLING, RUTH HASLAM, and N. WALD

23 Interchangeable Cells for Spectrophotometers and Fluorimeters September 1971 S. S. BROWN and A. H. GOWENLOCK

24 Simple Tests to Detect Poisons March 1972 B. w. MEADE et al.

25 Blood Gas Analysers May 1972 K. DIXoN

26 Kits for Enzyme Activity Determination September 1972 S. B. ROSALKI and D. TARLOW

27 Assessment of Pumps Suitable for Incorporation into Existing Continuous Flow Analytical Systems November 1972 A. FLECK et al.

28 Routine Clinical Measurements of Transferrin in Human Serum September 1973 K. DIXON

29 Control Materials for Clinical Biochemistry (5th edition) September 1973 J. F. STEVENS

30 Notes on the Quality of Performance of Serum Cholesterol Assays September 1973 s. S. BROWN

31 Determination of Uric Acid in Blood and in Urine July 1974 R. W. E. WATTS

32 A Survey of Amino Acid Analysers Readily Available in the United Kingdom September 1974 J. E. CARLYLE and P. PURKISS

33 Definitions of some Words and Terms used in Automated Analysis November 1974 A. FLECK, R. ROBINSON, S. S. BROWN, and J. R. HOBBS

34 Measurement of Albumin in the Sera of Patients January 1975 LINDA SLATER, P. M. CARTER, and J. R. HOBBS

35 Investigation of the Validity of Temperature Correction Factors for Serum Aspartate and Alanine Transaminases March 1975 S. B. ROSALKI et al.

36 Factors Influencing the Assay of Creatinine November 1975 J. G. H. COOK 